\title{
PERBEDAAN KONSUMSI CAIRAN DAN STATUS HIDRASI PADA REMAJA OBESITAS DAN NON OBESITAS
}

\author{
Sigit Oktaviyani Prayitno, Fillah Fithra Dieny ${ }^{*}$ \\ Program Studi Ilmu Gizi Fakultas Kedokteran Universitas Diponegoro \\ Jl.Dr.Sutomo No.14, Semarang, Telp (024) 8453708, Email : gizifk@undip.ac.id
}

\begin{abstract}
Background: Dehydration on adolescent is more increasing, it was caused by low fluid intake. Obese adolescents are susceptible to dehydration than nonobese adolescents. Whereas many studies find that fluid intake on obese adolescents is higher than nonobese adolescents. The aimed of this study to knew the difference of fluid intake and hydration status on obese and nonobese adolescents.

Method: Observational research with cross sectional design, setting of this study was in Al Azhar Islamic 14 junior high school with 31 obese and 31 nonobese adolescents as subjects selected by consecutive random sampling. Data included characteristic of subjects; fluid intake; hydration status; drinking habits of the frequency, type, and source; and knowledge about fluid. Fluid intake was measured by $3 \times 24$ hours recall and hydration status was observed by urine-color graph. Drinking habits and knowledge about fluid were measured with questionnaire.

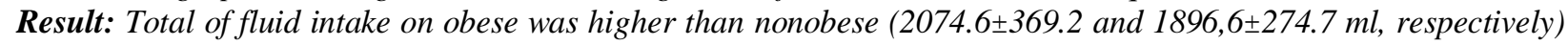
with $p=0,035$, but dehydration was more susceptible on obese adolescents (83.9\%) than nonobese adolescents $(51.6 \%)$ with $p=0,024$.
\end{abstract}

Conclusion: There was a difference of fluid intake and hydration status between obese and nonobese adolescent.

Keyword: fluid intake; hydration status; obese; adolescents

\begin{abstract}
ABSTRAK
Latar Belakang : Dehidrasi pada remaja semakin meningkat, hal ini disebabkan karena kurangnya konsumsi cairan pada remaja. Remaja obesitas lebih mudah mengalami dehidrasi dibanding remaja non obesitas. Padahal konsumsi cairan remaja obesitas dari beberapa penelitian diketahui lebih tinggi dibanding remaja non obesitas. Tujuan dari penelitian ini untuk mengetahui perbedaan konsumsi cairan dan status hidrasi pada remaja obesitas dan non obesitas.

Metode : Penelitian observasional dengan pendekatan cross sectional, bertempat di SMP Islam Al Azhar 14 Semarang dengan jumlah sampel 31 remaja obesitas dan 31 remaja non obesitas yang dipilih dengan consecutive random sampling. Data yang dikumpulkan meliputi karakteristik subjek, konsumsi cairan, status hidrasi, kebiasaan minum yang terdiri dari frekuensi, jenis, dan sumber minuman, dan pengetahuan tentang cairan. Konsumsi cairan diukur menggunakan recall selama $3 \times 24$ jam dan status hidrasi dilihat menggunakan grafik warna urine. Kebiasaan minum dan pengetahuan cairan diukur dengan kuesioner.

Hasil : Total konsumsi cairan pada remaja obesitas lebih tinggi dibandingkan non obesitas $(2074,6 \pm 369,2$ berbanding 1896,6 $\pm 274,7 \mathrm{ml}$ ) dengan p=0,035, namun kejadian dehidrasi lebih banyak dialami remaja obesitas $(83,9 \%)$ dibanding non obesitas $(51,6 \%)$ dengan $p=0,024$.
\end{abstract}

Simpulan : Terdapat perbedaan konsumsi cairan dan status hidrasi antara remaja obesitas dan non obesitas.

Kata kunci : konsumsi cairan; status hidrasi; obesitas; remaja

\section{PENDAHULUAN}

Kurangnya konsumsi air pada remaja menjadi masalah gizi karena remaja rentan mengalami dehidrasi yang disebabkan oleh banyaknya aktivitas fisik yang menguras tenaga dan juga cairan tubuh. ${ }^{1,2}$ Kehilangan cairan tubuh atau dehidrasi ini lebih sering dialami oleh anakanak, remaja dan lansia, tetapi juga bisa dialami oleh kategori usia lainnya. Terbukti dari hasil penelitian The Indonesian Regional Hydration Study (THIRST) di beberapa kota di Indonesia, sebesar $46,1 \%$ penduduk Indonesia mengalami dehidrasi ringan, jumlah tersebut lebih tinggi pada remaja $(49,5 \%)$ dibanding orang dewasa $(42,5 \%) .{ }^{1}$ Penelitian lain pada remaja awal di Bogor menemukan sebesar $62,8 \%$ remaja mengalami dehidrasi ringan. ${ }^{3}$

Dehidrasi dapat menjadi faktor risiko terjadinya obesitas pada anak dan remaja. ${ }^{4}$ Hal ini disebabkan karena adanya ketidakseimbangan elektrolit dalam tubuh yang memacu meningkatnya nafsu makan dan asupan makanan yang kaya lemak sehingga asupan cairan dalam tubuh terus menurun. ${ }^{5}$ Dehidrasi pada remaja obesitas 
menyebabkan penurunan fungsi kognisi dan mood, juga meningkatkan kelelahan sehingga tubuh menjadi lemas dan malas untuk beraktivitas fisik. ${ }^{6}$ Kebiasaan minum sebelum makan dapat menjadi alternatif cara untuk mencegah dehidrasi juga sebagai terapi penurunan berat badan pada remaja obesitas. Penelitian di Virginia pada orang obesitas menemukan bahwa konsumsi air sebelum makan dapat menurunkan asupan makan sampai $13 \%{ }^{7}$

Pemilihan jenis konsumsi cairan yang mengandung gula tinggi dapat menjadi faktor obesitas karena minuman bergula tinggi menyumbang kalori yang cukup banyak bagi tubuh. ${ }^{8} \quad$ Sehingga beberapa penelitian menganjurkan untuk mengganti konsumsi minuman manis berkalori tinggi tersebut dengan konsumsi air putih pada orang obesitas. Penelitian di Kanada menunjukkan terdapat beda jenis konsumsi cairan pada remaja obesitas dan non obesitas, minuman bergula tinggi lebih banyak ( $>3$ kali/hari) dikonsumsi remaja obesitas dibandingkan remaja non obesitas (<3 kali/hari) ${ }^{9,10}$ Substitusi dari minuman bergula tinggi ke konsumsi air putih dilakukan sebagai upaya pencegahan dan salah satu bentuk terapi untuk menurunkan obesitas, termasuk pada remaja yang diketahui pemenuhan konsumsi cairannya masih kurang.

Hasil penelitian tentang kebiasaan minum remaja dan asupan cairan remaja perkotaan di Bogor menemukan bahwa terdapat $37,3 \%$ remaja yang minum kurang dari 8 gelas per hari dan sebesar $24,1 \%$ remaja asupan cairannya kurang dari $90 \%$ kebutuhan. ${ }^{3}$ Survey NHANES II (19992002) di Amerika menemukan perbedaan konsumsi cairan baik dari makanan maupun minuman pada remaja yang obesitas dan non obesitas diketahui lebih banyak pada remaja obesitas sebesar 2,4 liter. ${ }^{11}$ Hal ini didukung oleh hasil survey NHANES III (2005-2006) yang menemukan bahwa konsumsi total cairan pada remaja obesitas lebih tinggi dibanding remaja non obesitas, yaitu 2,2 liter berbanding 1,9 liter. $^{12}$

Meskipun konsumsi cairannya sudah lebih tinggi pada remaja obesitas, namun dilihat dari kebutuhan cairan yang seharusnya sebesar 2,4 - 3,3 liter, pemenuhan konsumsi cairan pada remaja obesitas tergolong masih kurang dari standar kebutuhan cairan. Hal ini dikarenakan kandungan air di dalam sel lemak orang yang mengalami obesitas lebih rendah daripada kandungan air dalam sel otot. Perbandingan antara air dan lemaknya berbanding 50\% : 50\% lebih rendah dibandingkan dengan orang yang berat badannya normal sehingga orang obesitas lebih mudah kekurangan cairan. ${ }^{13,14,15}$

Terjadinya penumpukan lemak tubuh pada orang obesitas dapat meningkatkan berat badan tanpa menambah kandungan air dalam tubuh. ${ }^{15}$ Oleh karena itu kebutuhan air bagi orang obesitas disarankan 2 gelas lebih banyak dari standar kebutuhan dibandingkan orang normal, selain karena faktor lebih mudah dehidrasi, konsumsi air yang cukup diketahui juga membantu menurunkan berat badan sehingga dapat menjadi cara baru untuk menurunkan kejadian obesitas. ${ }^{16}$

Penelitian sebelumnya di SMP Islam Al Azhar 14 Semarang menemukan prevalensi obesitas pada remaja 11-14 tahun sebanyak $35,1 \%{ }^{15}$ Berdasarkan latar belakang tersebut, maka tujuan penelitian ini untuk mengetahui perbedaan konsumsi cairan dan status hidrasi pada remaja obesitas dan non obesitas.

\section{METODE}

Penelitian ini dilaksanakan di SMP Islam Al Azhar 14 Semarang pada bulan Mei 2012. Penelitian ini termasuk lingkup gizi masyarakat dan merupakan studi observasional dengan desain cross sectional.

Populasi pada penelitian ini adalah seluruh siswa-siswi kelas 1 dan 2 sejumlah 222 orang. Pengambilan subjek diawali dengan melakukan skrining terhadap seluruh siswa-siswi untuk menentukan status gizi. Status gizi ditentukan berdasarkan persentil Indeks Massa Tubuh (IMT) per umur menurut grafik pertumbuhan Center for Disease Control (CDC) untuk usia 2-20 tahun. Subjek yang memiliki persentil $>95^{\text {th }}$ dikategorikan obesitas dan yang memiliki persentil $5-85^{\text {th }}$ dikategorikan non obesitas. Jumlah subjek minimal sebanyak 30 subjek, dan dalam penelitian ini diperoleh 31 subjek untuk masing-masing kelompok obesitas dan non obesitas sehingga total subjek dalam penelitian ini berjumlah 62 subjek. Subjek diambil dengan cara consecutive random sampling. Kriteria inklusi yaitu siswa-siswi kelas 1 dan 2, berbadan sehat (suhu tubuh normal $=36^{\circ} \mathrm{C}$ $37^{\circ} \mathrm{C}$ ), dan memiliki status gizi obesitas atau non obesitas.

Data yang dikumpulkan dalam penelitian ini adalah identitas subjek, status obesitas, konsumsi cairan, kebiasaan minum, pengetahuan tentang cairan dan status hidrasi. Konsumsi cairan adalah cairan yang masuk dalam tubuh yang berasal dari minuman dan makanan. Total konsumsi cairan diperoleh dari dietary recall selama $3 \times 24$ jam pada 2 hari aktif sekolah dan 1 
hari libur. Perhitungan jumlah total konsumsi cairan menggunakan rumus menambahkan total cairan dari minuman dan total cairan dari makanan yang dilihat dari DKBM 2005, kemudian dihitung rata-rata total konsumsi cairan selama $3 \times 24$ jam.

Kebiasaan minum adalah segala sesuatu yang berhubungan dengan minum dan minuman seperti frekuensi minum, kebiasaan minum sebelum makan, jenis minuman, waktu minum, dan sumber minuman yang dikonsumsi (bekal dari rumah). Gambaran kebiasaan minum diperoleh dari kuesioner dan formulir food frequency ( $F F Q)$ semi kuantitatif. Frekuensi minum dikategorikan menjadi 3 yaitu 3-4 kali sehari, 5-6 kali sehari dan $>6$ kali sehari, untuk mengetahui frekuensi minum air putih. Frekuensi minum minuman lainnya dikategorikan menjadi 4 yaitu tidak pernah (0 kali per minggu), jarang (1-3 kali per minggu), kadangkadang (4-6 kali per minggu), dan sering (>6 kali per minggu). Kebiasaan minum sebelum makan dan bekal dari rumah diperoleh dari kuesioner dengan jawaban ya atau tidak. Jenis minuman yang dikonsumsi diperoleh dari formulir food frequency semi kuantitatif meliputi konsumsi air putih kemasan dan non kemasan, susu kemasan dan non kemasan, teh kemasan dan non kemasan, soft drink, dan jus buah. Waktu minum diketahui dari kuesioner meliputi saat haus, setelah makan dan setelah olahraga.

Jenis kelamin diperoleh dari identitas subjek meliputi laki-laki dan perempuan. Pengetahuan dan jenis kelamin digunakan sebagai kontrol untuk melihat perbedaan konsumsi cairan dan status hidrasi. Pengetahuan tentang pentingnya cairan, fungsi, sumber dan jenis cairan cairan didapatkan melalui wawancara terstandar. Nilai jawaban untuk masing-masing pertanyaan yaitu 4 untuk jawaban benar dan 0 untuk jawaban salah, dengan total nilai 100. Setelah dihitung, skor pengetahuan kemudian dikategorikan menjadi 3 yaitu baik apabila nilai $\geq 80$, cukup apabila nilai antara 61-79 dan kurang apabila nilai $\leq 60$.
Status hidrasi adalah suatu kondisi atau keadaan yang menggambarkan jumlah cairan dalam tubuh seseorang yang dapat diketahui dari pengujian warna urin kartu Periksa Urin Sendiri (PURI). Pengambilan sampel urin pada pagi hari dengan menggunakan bantuan botol kaca bening. Setelah urin didapat, kemudian dicocokkan warnanya menggunakan grafik warna urin kartu PURI di bawah sinar lampu neon putih atau sinar matahari untuk menentukan kadar hidrasinya. ${ }^{18}$ Ketentuan warna urin yaitu apabila 1-3 maka subjek terhidrasi dengan baik, 4-8 maka subjek mengalami dehidrasi.

Pengolahan dan analisis data dilakukan dengan program komputer. Untuk mengetahui perbedaan konsumsi cairan pada remaja obesitas dan non obesitas yang sebelumnya diuji normalitas data menggunakan Kolmogorov-Smirnov, selanjutnya digunakan uji independent t-test, sedangkan untuk mengetahui perbedaan status hidrasi pada remaja obesitas dan non obesitas serta mengetahui perbedaan konsumsi cairan dan status hidrasi berdasarkan pengetahuan tentang cairan digunakan uji Mann-Whitney.

\section{HASIL PENELITIAN \\ Karakteristik Subjek Penelitian}

Jumlah siswa-siswi kelas 1 dan 2 SMP

Islam Al Azhar 14 Semarang adalah 222 orang.

Berdasarkan hasil penyaringan awal ditemukan angka prevalensi obesitas sebesar 26,6\%. Prevalensi obesitas tersebut terdiri dari 36 orang laki-laki dan 23 orang perempuan. Dari prevalensi tersebut, diambil subjek pada penelitian ini masing-masing 31 subjek. Masing-masing kelompok obesitas dan non obesitas terdiri dari 17 subjek berjenis kelamin laki-laki dan 14 subjek perempuan. Subjek penelitian berusia antara 13-14 tahun. Rerata persentil IMT/U pada obesitas yaitu $98,5^{\text {th }} \pm 1,33$, sedangkan pada non obesitas yaitu $16,9^{\text {th }} \pm 8,84$. Karakteristik subjek dapat dilihat pada tabel 1 .

Tabel 1. Karakteristik subjek menurut usia, berat badan, tinggi badan, nilai IMT, persentil IMT/U dan skor pengetahuan tentang cairan

\begin{tabular}{lcccccc}
\hline Karakteristik & \multicolumn{3}{c}{ Obesitas $(\mathrm{n}=31)$} & \multicolumn{3}{c}{ Non Obesitas $(\mathrm{n}=31)$} \\
subjek & $\min$ & maks & rerata \pm SD & min & maks & rerata \pm SD \\
\hline Berat badan $(\mathrm{kg})$ & 56,8 & 105,6 & $73,8 \pm 11,88$ & 35 & 48,5 & $41,5 \pm 4,33$ \\
Tinggi badan $(\mathrm{cm})$ & 149 & 178,5 & $160,4 \pm 7,24$ & 143,3 & 175 & $156,7 \pm 7,76$ \\
IMT $\left(\mathrm{kg} / \mathrm{cm}^{2}\right)$ & 23,9 & 40,7 & $28,7 \pm 4,14$ & 15,5 & 18,3 & $16,9 \pm 0,77$ \\
Persentil IMT/U & 95,7 & 99,99 & $98,5 \pm 1,33$ & 5,3 & 38,6 & $16,9 \pm 8,84$ \\
$\left(^{\text {th }}\right.$ ) & 64 & 92 & $79,3 \pm 8,23$ & 72 & 96 & $82,2 \pm 6,35$ \\
$\begin{array}{l}\text { Skor Pengetahuan } \\
\text { tentang Cairan }\end{array}$ & & & & & & \\
\hline
\end{tabular}




\section{Pengetahuan tentang Cairan}

Berdasarkan tabel 1, skor pengetahuan tentang cairan pada non obesitas yaitu $82,2 \pm 6,35$ sedangkan pada obesitas yaitu $79,3 \pm 8,23$. Tidak terdapat perbedaan pengetahuan tentang cairan antara remaja obesitas dan non obesitas $(p=0,180)$ karena diketahui skor pengetahuan tentang cairan subjek rata-rata sudah baik. Subjek non obesitas memiliki pengetahuan baik sebesar $77,4 \%$ sedangkan subjek obesitas 51,6\%. Pengetahuan tentang cairan antara remaja obesitas dan non obesitas dapat dilihat pada tabel 2 .

Tabel 2. Pengetahuan tentang cairan antara remaja obesitas dan non obesitas

\begin{tabular}{|c|c|c|c|c|c|c|}
\hline & \multicolumn{2}{|c|}{ Obesitas $(n=31)$} & \multicolumn{2}{|c|}{$\begin{array}{c}\text { Non Obesitas } \\
\quad(n=31)\end{array}$} & \multirow[t]{2}{*}{$\mathrm{p}$ value } \\
\hline & & $\mathrm{n}$ & $\%$ & $\mathrm{n}$ & $\%$ & \\
\hline Pengetahuan & tentang & & & & & 0.180 \\
\hline Cairan & & 16 & 51,6 & 24 & 77,4 & \\
\hline $\begin{array}{l}\text { Baik } \\
\text { Cukup }\end{array}$ & & 15 & 48,4 & 7 & 22,6 & \\
\hline
\end{tabular}

\section{Konsumsi Cairan pada Remaja Obesitas dan Non Obesitas}

Nilai minimum, maksimum, rerata dan putih, konsumsi minuman lainnya dan cairan dari makanan dapat dilihat pada tabel 3 . standar deviasi total konsumsi cairan, konsumsi air

Tabel 3. Nilai minimum, maksimum, rerata dan standar deviasi total konsumsi cairan, konsumsi air putih,

konsumsi minuman lainnya dan cairan dari makanan

\begin{tabular}{|c|c|c|c|c|c|c|c|}
\hline & \multicolumn{3}{|c|}{ Obesitas $(n=31)$} & \multicolumn{3}{|c|}{ Non Obesitas $(\mathrm{n}=31)$} & \multirow[t]{2}{*}{$p$ value } \\
\hline & $\min$ & maks & rerata $\pm S D$ & $\min$ & maks & rerata $\pm \mathrm{SD}$ & \\
\hline $\begin{array}{l}\text { Total } \\
\text { konsumsi } \\
\text { cairan (ml) }\end{array}$ & 1502 & 3219 & $\begin{array}{c}2074,6 \pm 369 \\
2\end{array}$ & $\begin{array}{c}1492, \\
6\end{array}$ & 2823,4 & $\begin{array}{c}1896,6 \pm 274 \\
7\end{array}$ & $0.035 *$ \\
\hline $\begin{array}{l}\text { Konsumsi } \\
\text { airputih (ml) }\end{array}$ & 240 & $\begin{array}{c}1693 \\
3\end{array}$ & $994,9 \pm 383,6$ & 460 & 1973,3 & $962,8 \pm 387,5$ & 0.744 \\
\hline $\begin{array}{l}\text { Konsumsi } \\
\text { minuman } \\
\text { lainnya (ml) }\end{array}$ & 240 & $\begin{array}{l}1366 \\
7\end{array}$ & $651,7 \pm 312,1$ & 0 & 1116,7 & $\begin{array}{c}8 \\
531,4 \pm 245,4\end{array}$ & 0.097 \\
\hline $\begin{array}{l}\text { Cairan dari } \\
\text { makanan } \\
\text { (ml) }\end{array}$ & $\begin{array}{c}197 \\
3\end{array}$ & 709,3 & 5 & 115,3 & 747,8 & 5 & 0.318 \\
\hline & & & $437,2 \pm 110,4$ & & & $\begin{array}{c}408,1 \pm 116,5 \\
9\end{array}$ & \\
\hline
\end{tabular}

Tabel 3 menunjukkan hasil bahwa terdapat perbedaan total konsumsi cairan antara remaja obesitas dan non obesitas $(p=0,035 ; \mathrm{t}=-2.154)$, dimana rerata konsumsi cairan pada remaja obesitas sebesar $2074,6 \pm 369,2 \mathrm{ml}$ sedangkan pada remaja non obesitas sebesar $1896,6 \pm 274,7 \mathrm{ml}$. Namun tidak ditemukan perbedaan konsumsi air putih, konsumsi minuman lainnya dan cairan dari makanan pada remaja obesitas dan non obesitas $(p=0,744 ; p=0,097 ; p=0,318)$.

Konsumsi air putih lebih banyak dibandingkan konsumsi minuman lainnya maupun cairan dari makanan. Konsumsi air putih menyumbang sebesar $50,8 \%$ dari total konsumsi cairan pada non obesitas, sedangkan pada obesitas menyumbang sebesar $47,5 \%$. Konsumsi minuman lainnya berkontribusi sebesar $31,4 \%$ dari total konsumsi cairan pada obesitas, sedangkan pada non obesitas hanya $28 \%$. Cairan dari makanan pada obesitas dan non obesitas menyumbang sebesar 21\%. Terdapat subjek yang hanya mengkonsumsi air putih pada non obesitas.

Berdasarkan tujuan penelitian, pengetahuan tentang cairan dan jenis kelamin merupakan variabel kontrol untuk melihat perbedaan konsumsi cairan dan status hidrasi. Oleh 
karena itu dilakukan uji beda untuk melihat perbedaan konsumsi cairan berdasarkan pengetahuan tentang cairan dan jenis kelamin pada remaja obesitas dan non obesitas. Diketahui tidak terdapat perbedaan konsumsi cairan berdasarkan jenis kelamin maupun pengetahuan tentang cairan $(p=0,515 ; p=0,055)$. Sehingga dapat disimpulkan bahwa variabel jenis kelamin dan pengetahuan tentang cairan bukan merupakan variabel perancu dalam penelitian.

\section{a. Kebiasaan Minum}

Karakteristik kebiasaan minum sebelum makan, frekuensi minum dan kebiasaan waktu minum antara remaja obesitas dan non obesitas dapat dilihat pada tabel 4 .

Tabel 4. Karakteristik kebiasaan minum sebelum makan, frekuensi minum dan kebiasaan waktu minum antara obesitas dan non obesitas

\begin{tabular}{|c|c|c|c|c|}
\hline & \multicolumn{2}{|c|}{ Obesitas $(n=31)$} & \multicolumn{2}{|c|}{ Non Obesitas $(\mathrm{n}=31)$} \\
\hline & $\mathrm{n}$ & $\%$ & $\mathrm{n}$ & $\%$ \\
\hline \multicolumn{5}{|l|}{ Kebiasaan minum sebelum } \\
\hline Ya & 12 & 38,7 & 8 & 25,8 \\
\hline \multicolumn{5}{|l|}{ Tidak } \\
\hline Frekuensi minum & 22 & 71 & 23 & 74,2 \\
\hline$<8$ kali sehari & 9 & 29 & 8 & 25,8 \\
\hline 8-12 kali sehari & 0 & 0 & 0 & 0 \\
\hline \multicolumn{5}{|l|}{$>12$ kali sehari } \\
\hline Frekuensi minum air putih & 13 & 41,9 & 15 & 48,4 \\
\hline 1-3 kali per hari & 17 & 54,8 & 13 & 41,9 \\
\hline 4-6 kali per hari & 1 & 3,3 & 3 & 9,7 \\
\hline \multicolumn{5}{|l|}{$>6$ kali per hari } \\
\hline \multicolumn{5}{|l|}{ Frekuensi minum minuman } \\
\hline lainnya & 0 & 0 & 1 & 3,3 \\
\hline Tidak pernah & 26 & 83,9 & 28 & 90,3 \\
\hline 1-3 kali per hari & 5 & 16,1 & 2 & 6,4 \\
\hline \multicolumn{5}{|l|}{ 4-6 kali per hari } \\
\hline Kebiasaan waktu minum & 23 & 74,2 & 21 & 67,8 \\
\hline Saat haus & 7 & 22,5 & 10 & 32,2 \\
\hline Setelah makan & 1 & 3,3 & 0 & 0 \\
\hline Setelah olahraga & & & & \\
\hline
\end{tabular}

Kebiasaan minum sebelum makan antara obesitas dan non obesitas lebih banyak dilakukan pada non obesitas yaitu $74,2 \%$. Frekuensi minum normal antara 8-12 kali sehari pada obesitas lebih banyak yaitu $29 \%$, dibandingkan pada non obesitas yaitu $25,8 \%$. Pada kelompok obesitas hanya 3,3\% yang memiliki frekuensi minum air putih $>6$ kali per hari, sedangkan pada non obesitas lebih tinggi yaitu 9,7\%. Pada kelompok non obesitas sebesar $3,3 \%$ subjek tidak mengkonsumsi minuman lainnya.

Frekuensi minum minuman manis antara 4-6 kali sehari pada subjek yang obesitas lebih tinggi yaitu $16,1 \%$, sedangkan pada non obesitas hanya $6,4 \%$. Sebagian besar subjek memiliki kebiasaan waktu minum saat haus. Kebiasaan tersebut lebih tinggi pada obesitas yaitu sebesar $74,2 \%$, sedangkan pada non obesitas sebesar $67,8 \%$. Hanya $3,3 \%$ subjek obesitas yang memiliki kebiasaan minum setelah berolahraga.

\section{b. Jenis dan Sumber Minuman}

Distribusi frekuensi jenis minuman selain air putih dan sumber minuman dapat dilihat pada tabel 5. 
Tabel 5. Distribusi frekuensi jenis minuman selain air putih dan sumber minuman

\begin{tabular}{lcccc}
\hline Karakteristik & \multicolumn{2}{c}{ Obesitas $(\mathrm{n}=31)$} & \multicolumn{2}{c}{ Non Obesitas $(\mathrm{n}=31)$} \\
& $\mathrm{n}$ & $\%$ & $\mathrm{n}$ & $\%$ \\
\hline Jenis minuman selain air & 19 & 61,3 & 16 & 51,6 \\
putih & 12 & 38,7 & 8 & 25,8 \\
$\quad$ Susu non kemasan & 6 & 19,35 & 6 & 19,35 \\
$\quad$ Susu kemasan & 15 & 48,4 & 10 & 32,3 \\
$\quad$ Teh non kemasan & 8 & 25,8 & 12 & 38,7 \\
$\quad$ Teh kemasan & 8 & 25,8 & 3 & 9,7 \\
$\quad$ Jus buah & 2 & 6,45 & 1 & 3,3 \\
$\quad$ Soft drink & & & & \\
$\quad$ Sirup & & & & \\
Sumber minuman & 11 & 35,5 & 7 & 22,6 \\
$\quad$ Bekal dari rumah & 20 & 64,5 & 24 & 78,4 \\
$\quad$ Ya & & & & \\
$\quad$ Tidak & & &
\end{tabular}

Sebagian besar jenis minuman selain air putih lebih banyak dikonsumsi pada obesitas. Hanya jus buah yang dikonsumsi lebih banyak pada non obesitas. Jenis minuman yang paling banyak dikonsumsi pada obesitas dan non obesitas adalah susu non kemasan yaitu $56,45 \%$ dari total seluruh subjek. Konsumsi soft drink pada obesitas lebih tinggi yaitu $25,8 \%$ dibandingkan pada non obesitas yaitu $9,7 \%$. Subjek yang membawa bekal minuman dari rumah lebih banyak pada obesitas yaitu sebesar $35,5 \%$, sedangkan pada non obesitas sebesar $22,4 \%$.

\section{Status Hidrasi pada Remaja Obesitas dan Non Obesitas \\ Terdapat perbedaan status hidrasi antara} obesitas dan non obesitas $(p=0,024)$. Kejadian dehidrasi lebih banyak dialami pada remaja obesitas. Sebanyak $83,9 \%$ remaja obesitas mengalami dehidrasi, sedangkan remaja non obesitas sebesar 51,6\%. Subjek yang terhidrasi dengan baik pada non obesitas yaitu sebesar $48,4 \%$ sedangkan pada obesitas hanya sebesar $16,1 \%$.

Diketahui tidak terdapat perbedaan status hidrasi berdasarkan jenis kelamin $(p=0,186)$. Namun pengetahuan tentang cairan diketahui signifikan mempengaruhi perbedaan status hidrasi $(p=0,003)$. Status hidrasi pada remaja obesitas dan non obesitas dapat dilihat pada tabel 6 .

Tabel 6. Status hidrasi pada remaja obesitas dan non obesitas

\begin{tabular}{cccccc}
\hline & \multicolumn{2}{c}{ Obesitas $(\mathrm{n}=31)$} & \multicolumn{2}{c}{ Non Obesitas $(\mathrm{n}=31)$} & $p$ value \\
& $\mathrm{n}$ & $\%$ & $\mathrm{~N}$ & $\%$ & \\
\hline Status hidrasi & & & & & $0.024^{*}$ \\
Hidrasi baik & 5 & 16,1 & 15 & 48,4 & \\
Dehidrasi & 26 & 83,9 & 16 & 51,6 & \\
\hline
\end{tabular}

\section{PEMBAHASAN}

\section{Karateristik Subjek Penelitian}

Ditemukan prevalensi kejadian obesitas pada penelitian ini sebesar $26,6 \%$. Prevalensi ini lebih rendah dibandingkan penelitian yang dilakukan pada tahun 2008 di tempat yang sama yaitu dengan prevalensi $35,1 \% .{ }^{19}$ Namun, angka prevalensi tersebut masih tinggi bila melihat prevalensi obesitas pada penelitian lain di Semarang tahun 2007 dengan prevalensi $6,7 \%{ }^{20}$ Hal ini menunjukkan bahwa obesitas masih menjadi masalah pada remaja yang belum tertangani dengan baik dan prevalensinya masih cukup tinggi setiap tahunnya.

Subjek penelitian memiliki usia 13-14 tahun. Usia lebih dari 12 tahun akan mempengaruhi total air tubuh antara laki-laki dan perempuan, dimana pada laki-laki lebih banyak kandungan air tubuhnya dibandingkan perempuan karena laki-laki mempunyai massa tubuh yang lebih tinggi dibandingkan perempuan. ${ }^{3}$ Hal tersebut akan mempengaruhi kebutuhan cairan yang lebih tinggi pada laki-laki, juga kebutuhan akan zat gizi lainnya sehingga memicu terjadinya 
obesitas. Hasil penelitian menunjukkan kejadian obesitas lebih banyak dialami oleh laki-laki dibandingkan perempuan. Berbeda dengan penelitian sebelumnya yang menunjukkan kejadian obesitas lebih banyak dialami oleh perempuan dibanding laki-laki. ${ }^{19,20}$ Hal ini dapat dipengaruhi banyak faktor, salah satunya pengetahuan termasuk pengetahuan tentang cairan.

Hasil penelitian menunjukkan skor pengetahuan tentang cairan yang baik lebih tinggi pada subjek non obesitas $(77,4 \%)$ dibanding obesitas $(51,6 \%)$. Pengetahuan yang baik dapat mempengaruhi konsumsi cairan baik dalam hal kualitas maupun kuantitas, serta dalam kebiasaan minum sehari-harinya. Pengetahuan yang semakin baik akan mendorong seseorang untuk mengkonsumsi cairan sesuai kebutuhan dan memiliki kebiasaan minum yang lebih baik pula sehingga risiko mengalami dehidrasi lebih kecil, begitupun sebaliknya. ${ }^{1}$

\section{Konsumsi Cairan pada Remaja Obesitas dan Non Obesitas}

Total konsumsi cairan pada penelitian ini menunjukkan bahwa pada remaja obesitas dan non obesitas sekitar 79\% total konsumsi cairan diperoleh dari minuman, sementara $21 \%$ sisanya diperoleh dari makanan. Hasil ini hampir serupa dengan penelitian lain yang menyatakan bahwa pada usia anak dan dewasa sekitar $80 \%$ total intake air diperoleh dari minuman dan $20 \%$ sisanya dari makanan. $^{25}$ Konsumsi cairan paling banyak diperoleh dari konsumsi air putih baik pada remaja obesitas $(47,5 \%)$ maupun non obesitas $(50,8 \%)$. Penelitian lain juga menyatakan air putih sebagai penyumbang cairan terbesar pada remaja yaitu sebesar $50,9 \%$. $^{3}$

Terdapat perbedaan total konsumsi cairan pada remaja obesitas dan non obesitas $(p=0.035)$. Konsumsi cairan lebih tinggi pada remaja obesitas $(2074,6 \pm 369,2 \mathrm{ml})$ dibanding non obesitas $(1896,6 \pm 274,7 \mathrm{ml})$. Hal ini sesuai dengan penelitian sebelumnya, yang menunjukkan adanya perbedaan konsumsi cairan pada remaja obesitas dan non obesitas, konsumsi cairan lebih banyak dikonsumsi remaja obesitas dibanding non obesitas (2,2 L berbanding 1,9 L). ${ }^{12}$ Meskipun konsumsi cairan pada remaja obesitas lebih tinggi dibanding remaja non obesitas, namun jumlah tersebut masih kurang dari pemenuhan kebutuhan cairan yang seharusnya dikonsumsi remaja obesitas. Jika dibandingkan dengan anjuran gizi seimbang bahwa asupan air putih sehari kurang lebih 8 gelas atau setara dengan $2 \mathrm{~L}$, maka konsumsi cairan pada remaja obesitas dan non obesitas juga masih tergolong kurang.

Selain kebiasaan makan, remaja juga memiliki kebiasaan minum. Hasil penelitian menunjukkan kebiasaan minum sebelum makan lebih banyak dilakukan pada non obesitas $(74,2 \%)$ dibanding obesitas $(61,3 \%)$. Beberapa penelitian lain menunjukkan bahwa kebiasaan minum sebelum makan dapat menjadi terapi untuk menurunkan berat badan pada obesitas. ${ }^{21}$ Penelitian lain menemukan bahwa kebiasaan mengkonsumsi air putih sebelum makan diketahui dapat menurunkan asupan makan sampai 13\% sehingga akan menurunkan berat badan. ${ }^{7}$

Anjuran minum 8 gelas sehari hanya dilakukan oleh $27,4 \%$ dari subjek penelitian. Hal ini tidak sesuai dengan teori yang menganjurkan untuk minum \pm 8 gelas sehari atau setara dengan 2 L. Penelitian lainnya juga menemukan hal yang sama, sebanyak $37,3 \%$ termasuk dalam kategori kurang minum air putih $\left(<8\right.$ gelas sehari) ${ }^{3}$ Studi di Hongkong juga menunjukkan hasil yang sama, sebesar 50\% subjek penelitiannya minum air putih kurang dari 8 gelas sehari, dan 30\% lainnya minum kurang dari 5 gelas sehari. ${ }^{22}$ Frekuensi minum air putih akan memberikan gambaran kecukupan kebutuhan cairan tubuh pada remaja.

Frekuensi minum minuman lainnya antara 1-3 kali sehari lebih tinggi pada non obesitas $(90,3 \%)$ dibanding obesitas (83,9\%). Sebesar 3,3\% subjek non obesitas diketahui tidak pernah mengkonsumsi minuman lain selain air putih. Penelitian lain juga menunjukkan frekuensi minum minuman lain yang bergula tinggi lebih banyak dilakukan remaja obesitas ( $>3$ kali sehari) dibanding remaja non obesitas $\left(<3\right.$ kali sehari) ${ }^{9}$

Sebesar $74,2 \%$ subjek obesitas memiliki kebiasaan waktu minum saat haus. Sebagian besar subjek non obesitas juga memiliki kebiasaan waktu minum yang sama. Penelitian lain juga menunjukkan bahwa sebesar $96,7 \%$ remaja memiliki kebiasaan minum ketika merasa haus. ${ }^{3}$ Padahal rasa haus sebenarnya merupakan tanda bahwa tubuh mengalami kekurangan cairan. Sehingga cairan harus diganti sebelum rasa haus ini timbul karena saat tubuh merasakan haus itu adalah pertanda tubuh sudah mengalami dehidrasi ringan. ${ }^{23}$

Jenis minuman yang dikonsumsi selain air putih, sangat beragam. Sebagian besar jenis minuman lainnya lebih banyak dikonsumsi pada obesitas. Konsumsi susu non kemasan yang paling banyak $(56,5 \%)$ dikonsumsi pada obesitas dan non obesitas. Hanya jus buah yang dikonsumsi paling 
banyak pada non obesitas. Hal ini menunjukkan bahwa subjek non obesitas lebih dapat memilih jenis minuman yang baik yaitu jus buah karena jus buah diketahui mengandung banyak vitamin dan zat gizi lainnya yang baik untuk tubuh dibanding mengkonsumsi minuman lain seperti soft drink.

Konsumsi soft drink pada obesitas $(25,8 \%)$ lebih tinggi dibanding non obesitas $(9,7 \%)$. Hal ini sesuai dengan penelitian lain yang menunjukkan bahwa subjek obesitas mengkonsumsi soft drink dan minuman manis lainnya lebih banyak dibanding non obesitas. ${ }^{10}$ Soft drink merupakan minuman mengandung kalori yang cukup tinggi yang dapat berkontribusi menyebabkan obesitas. Jumlah kalori pada soft drink dengan volume 300 $\mathrm{ml}$ rata-rata 150 kalori, setara dengan 3 sendok teh gula. Sehingga sebaiknya pada remaja yang sudah mengalami obesitas untuk mengurangi konsumsi soft drink atau dapat dengan mengganti konsumsi soft drink dengan air putih yang tidak berkalori.

Kebiasaan membawa bekal minuman dari rumah hanya dilakukan oleh $29 \%$ dari total subjek. Kebiasaan tersebut seharusnya dilakukan oleh semua subjek baik obesitas maupun non obesitas sebagai antisipasi agar tidak terlalu banyak mengkonsumsi minum minuman lainnya saat di sekolah. Seperti halnya dengan hasil penelitian lain yang menyatakan bahwa sebesar $34,9 \%$ remaja membawa bekal minuman 4-6 kali setiap minggunya. ${ }^{3}$

\section{Status Hidrasi pada Remaja Obesitas dan Non Obesitas}

Tubuh manusia setiap saat membutuhkan air. Tubuh kehilangan air melalui keringat, paruparu dan produksi urin. Banyak cara dan indikator yang dapat digunakan untuk mengukur status hidrasi. Tolok ukur status hidrasi yang baik bagi tubuh adalah warna dari urin. Pada penelitian ini warna urin subjek dilihat untuk menentukan status hidrasinya menggunakan grafik warna urin dari kartu Periksa Urin Sendiri (PURI). Grafik warna urin memiliki 8 tingkatan warna, masing-masing warna dapat digunakan untuk mengukur status hidrasi seseorang. Seseorang yang terhidrasi dengan baik mempunyai urin yang tidak berwarna. Semakin tinggi tingkat dehidrasinya maka urin yang keluar berwarna semakin gelap. ${ }^{15}$

Hasil penelitian menunjukkan ada perbedaan status hidrasi pada remaja obesitas dan non obesitas. Kejadian dehidrasi lebih banyak dialami remaja obesitas $(83,9 \%)$ dibanding non obesitas $(51,6 \%)$. Hal ini sesuai dengan teori bahwa remaja obesitas akan lebih mudah mengalami dehidrasi dibanding non obesitas karena kandungan air di dalam sel lemak pada orang obesitas lebih rendah daripada kandungan air dalam sel otot. ${ }^{13}$ Penelitian lain menunjukkan bahwa remaja yang obesitas memiliki risiko 1,35 kali lebih besar mengalami dehidrasi dibanding remaja normal. Penelitian di Bogor juga menemukan sebesar $62,8 \%$ subjek yang masih remaja mengalami dehidrasi ringan. ${ }^{1}$

\section{SIMPULAN}

Konsumsi cairan lebih tinggi pada remaja obesitas dibanding non obesitas namun kejadian dehidrasi lebih banyak dialami pada remaja obesitas dibanding remaja non obesitas.

\section{SARAN}

Perlunya meningkatkan asupan cairan bagi remaja obesitas dan non obesitas sesuai dengan kebutuhan cairan masing-masing untuk mencegah terjadinya dehidrasi. Selain itu, pentingnya memiliki kebiasaan minum sebelum makan dan mengganti konsumsi minuman manis dengan konsumsi air putih dapat menjadi terapi untuk menurunkan berat badan pada remaja obesitas.

\section{DAFTAR PUSTAKA}

1. Hardinsyah, Dodik Briawan, et al. Studi Kebiasaan Minum dan Status Hidrasi pada Remaja dan Dewasa di Wilayah Ekologi yang Berbeda. Bogor : Perhimpunan Peminat Gizi dan Pangan Indonesia (PERSAGI), Departemen Gizi Masyarakat FEMA IPB; 2009.

2. Briawan, Dodik, Hardinsyah, et al. Konsumsi Minuman dan Preferensinya pada di Jakarta dan Bandung. Jakarta : Perhimpunan Peminat Gizi dan Pangan Indonesia (PERSAGI); 2011.

3. Briawan, Dodik, Tyas Rara S, Ikeu Ekayanti. Kebiasaan Minum dan Asupan Cairan di Perkotaan. Jurnal Klinik Gizi Indonesia. 2011; Vol.8 No.1: 36-41.

4. Gustam, Hardinsyah, Dodik Briawan. Faktor Risiko Dehidrasi pada dan Dewasa. (skripsi). Departemen Gizi Masyarakat FEMA IPB; 2012.

5. Dehydration Linked To Obesity. 2004. http://www.water.org.uk/home/water-forhealth/medical-facts/obesity.

6. Lieberman, Harris R. Hydration and Cognition: A Critical Review and Recommendations for Future Research. Journal of the American College of Nutrition. 2007; Vol. 26:5, 555S-561S.

7. Davy, Brenda M, Elizabeth A.Dennis, et al. Water Consumption Reduces Energy Intake at a Breakfast Meal in Obesitas Older Adults. J Am Diet Assoc. 2008; 108(7): 1236-1239. 
8. Daniels, Melissa C., Barry M. Popkin. The Impact Of Water Intake On Energy Intake And Weight Status: A Systematic Review. Nutr Rev. 2010; 68(9): 505-521.

9. Gillis LJ, Bar-Or O. Food Away From Home, Sugar-Sweetened Drink Consumption And Juvenile Obesity. J Am Coll Nutr. 2003; 22: 53945.

10. Nicklas TA, Yang SJ, et all. Eating Patterns and Obesity in Children. The Bogalusa Heart Study. Am J Prev Med. 2003; 25:9-16.

11. Fulgoni, Victor L. Limitations of Data on Fluid Intake. Am Coll of Nutr. 2007; Vol.26, No.5: 588S-519S.

12. Kant, Ashima K., Barry I Graubard. Contributors of Water Intake in US Children and Adolescents: Associations with Dietary and Meal Characteristics-National Health and Nutrition Examination Survey 2005-2006. Am J Clin Nutr. 2010; 92: 887-96.

13. Yuniastuti, Ari. Air dan Cairan Tubuh. In: Gizi dan Kesehatan, 1st ed. Yogyakarta : Graha Ilmu, 2008; p.75-80.

14. Wardlaw, Gordon M, Anne M.Smith. Nutrients Involved in Fluid and Electrolyte Balance. In: Contemporary Nutrition a Functional Approach. New York : Mc.Graw-Hill International, 2009; p.300.

15. Batmanghelidj F. Air untuk Menjaga Kesehatan dan Menyembuhkan Penyakit. Jakarta : Gramedia Pustaka Utama; 2007.

16. Negoianu, Dan, Stanley Goldfarb, editors. Just Add Water. J Am Soc Nephrol. 2008; 19: 10411043.

17. Perhimpunan Dokter Gizi Medik Indonesia (PDGMI). Pentingnya Minum Air untuk Mencegah Dehidrasi.2010(cited 27 March 2012). Available from http://medicastore.com/seminar/106/Cegah_Dehidr asi_Ringan_dengan_Pemeriksaan_Urin_Sendiri_( PURI).html

18. Nurfaridah, Siti. Hubungan Antara Asupan Energi, Protein Dan Lemak Western Fast Food Serta Tingkat Aktifitas Fisik Dengan Obesity Pada Anak Smp Islam Al-Azhar 14 Semarang (skripsi). Program Studi Ilmu Gizi Fakultas Kedokteran Universitas Diponegoro; 2008.

19. Priyanto, Rudi. Besar Risiko Frekuensi Makan, Asupan Energi, Lemak, Serat dan Aktivitas Fisik terhadap Kejadian Obesitas pada Sekolah Menengah Pertama (SMP) (skripsi). Program Studi Ilmu Gizi Fakultas Kedokteran Universitas Diponegoro; 2008.

20. Tate, Deborah F., dkk. Replacing Caloric Beverages with Water or Diet Beverages for Weight Loss in Adults: Main Results of the Choose Healthy Options Consciously Everyday (CHOICE) Randomized Clinical Trial. Am J Clin Nutr; 2012: 555-63.
21. Asia Food Information Center (AFIC). Fluid the Forgotten Factor. Singapore : Asia Food Information Center; 2002.

22. Bossingham JM., Nadine SC., Wyne WC. Water Balance, Hydration Statues and Fat Free Mass Hydration in Younger and Older Adult. Am J Clin Nutr 2005; 81: 1342-1350.

23. Hardinsyah. Kebutuhan Air dalam Daur Kehidupan dan Permasalahnnya. Seminar Nasional Gizi Seimbang dan Peran Cairan untuk Berbagai Aktifitas Fisik; 21 Apr 2012. Jakarta: Unversitas Esa Unggul.

24. Manz F., Wentz A. Hydration Status in United States dan Germany. Nutr Rev 2005; 63: S55-62.

25. Rachma, Paramita. Kebiasaan Minum, Kebutuhan Cairan dan Kecenderungan Dehidrasi Siswi Sekolah Dasar (skripsi). Departemen Gizi Masyarakat FEMA IPB; 2009. 